\title{
The Determinants of Tax Compliance in Tax Amnesty Programs: Experimental Approach
}

\author{
Puri Mahestyanti' ${ }^{1}$ Bambang Juanda ${ }^{2}$, Lukytawati Anggraeni ${ }^{3}$
}

\begin{abstract}
In an effort of searching for a new source of revenue for funding the infrastructure development for Indonesia, the government chose to do tax amnesty in 2016. This research was conducted to study the effects of factors (wealth, tariff periods, tax penalties, and audit probability) towards tax compliance. Tax compliance measured from the number of units reported by taxpayers, the amount of value indicated by taxpayers, and participation from taxpayers. The study uses primary data that generated through experimental economics. The methods used are Variance Analysis. The result showed that the taxpayer with higher income has lower compliance rather than the taxpayer from lower income. The taxpayers prefer to report their assets at lower rates. The effort of enforcement from the government by implementing tax penalties and audit probability shows greater effect towards tax compliance.
\end{abstract}

Keywords: tax amnesty, tax compliance, variance analysis, experimental approach.

\begin{abstract}
Abstrak. Dalam rangka mencari sumber pendapatan baru, untuk pembiayaan pembangunan infrastruktur seluruh wilayan Indonesia, pemerintah memutuskan memilih melakukan amnesti pajak pada tahun 2016. Penelitian ini dilakukan sebagai sebuah kajian untuk mempelajari efek faktor-faktor (kekayaan, periode tarif, denda dan peluang audit probability) terhadap kepatuhan wajib pajak. Kepatuhan wajib pajak diukur dari unit harta yang diikutsertakan dari yang seharusnya dilaporkan, nilai harta yang diikutsertakan dari yang seharusnya dilaporkan, dan keikutsertaan wajib pajak. Penelitian ini menggunakan data primer yang dikumpulkan melalui serangkain percobaan ekonomi. Metode yang digunakan adalah uji ragam. Hasil penelitian menunjukkan bahwa wajib pajak dengan kekayaan tinggi memiliki tingkat kepatuhan yang rendah dan wajib pajak lebih menyukai untuk mengikuti amnesti pajak pada tingkat tarif terendah yakni pada 2\%. Upaya dari pemerintah dengan menerapkan denda dan peluang audit probability menunjukkan efek yang besar terhadap tingkat kepatuhan wajib pajak.
\end{abstract}

Kata Kunci: pengampunan pajak, kepatuhan pajak, analisis varians, pendekatan eksperimental.

\section{How to Cite:}

Mahestyanti, P., Juanda, B., \& Anggraeni, L. (2018). The Determinants of Tax Compliance in Tax Amnesty Programs: Experimental Approach. Etikonomi: Jurnal Ekonomi. Vol. 17 (1): 93 - 110. doi: http//dx.doi.org/10.15408/etk. v17i1.6966. 


\section{Introduction}

The plan of infrastructure droved the government to target National income at 1882,5 trillion rupiahs for the year 2016, with tax revenue targeted at 1360,2 trillion rupiah which is $74 \%$ of National income. However, until Mei 2016 the amount of tax revenue accepted is only 364,1 trillion rupiah, which is just $26.8 \%$ of the amount, targeted according to state budget (APBN) 2016. From the last two years, the amount of tax revenues has decreased by $82 \%$, which described in Figure 1. The government has, for the last two years, been intensely working on infrastructure development; this can see from the increase of tax target in 2015 and 2016. This condition drove the government to search for alternative fiscal policy as the new sources of fund.

Figure 1. Realization of Tax Revenue year 2011-2016

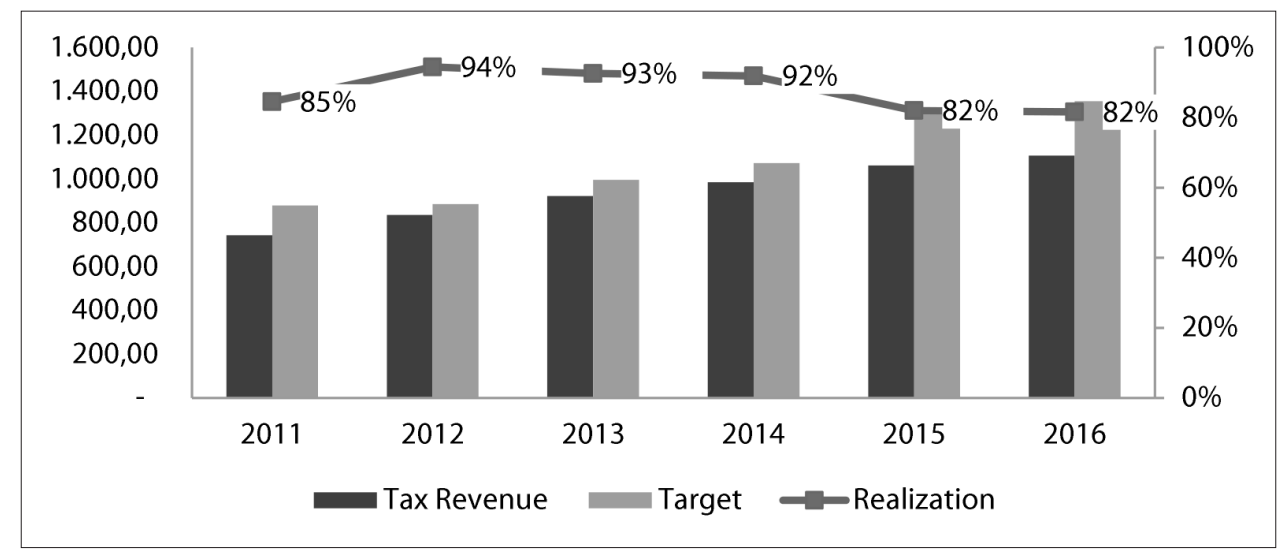

Besides that, Indonesia also faced by how low the level of tax compliance is. Table 1 that shows the reflection of tax compliance. Table 1 shows that in the year 2013 the amount of registered taxpayer or taxpayers who have tax ID number (NPWP) is around 24 million. According to census data, the number of a productive citizen in 2013 is approximately 90 million. The level of compliance also can be seen from the percentage of the amount of annual notification (SPT) registered from taxpayers. The rates are lies between 50\%-60\% that is considered low.

Challenged with the need for revenue for infrastructure development and how low tax compliance is in Indonesia, the government chose to do tax amnesty program. According to The Act number 11 of 2016, tax amnesty is the abolition of taxes that ought to be owed. This act is not a subject to sanctions of tax administration and criminal penalties in the filed of taxations of assets acquired in 2015 and earlier which have not been reported in the SPT by paying off all tax arrears owned and paying some tax ransoms.

Many of tax amnesty programs have brought succession such as a considerable amount of revenues and increased compliance with the previous tax offenders. Aside from raising revenue in short time, tax amnesty also acted as a smooth transition towards stricter tax system (Joulfian, 1998). Some of the countries have implemented tax amnesty programs such as Argentina, India (Le Borgne and Baer, 2008), South Africa and including Indonesia itself. 
Table 1. The Reflection of Tax Compliance

\begin{tabular}{ccccc}
\hline Year & Taxpayer Registered & Taxpayer required SPT & SPT registered & SPT compliance (\%) \\
\hline 2011 & $18,640,757$ & $17,694,317$ & $9,332,626$ & 52.74 \\
2012 & $22,030,583$ & $17,659,278$ & $9,482,480$ & 53.70 \\
2013 & $24,347,763$ & $17,731,736$ & $9,416,457$ & 53.11 \\
2014 & $27,945,570$ & $18,357,833$ & $10,828,808$ & 58.99 \\
2015 & $30,044,103$ & $18,159,840$ & $10,945,173$ & 60.27 \\
2016 & $32,769,255$ & $20,165,718$ & $12,269,290$ & 60.84 \\
\hline
\end{tabular}

According to Ragimun (2012), tax amnesty in South Africa applied a "Pull and Push Strategy." "Pull" is by giving incentives to taxpayers to attract them participating in the program, which is by invalidating the tax interest and giving tax ransoms at the lowest rates possible. "Push" strategy is by applying a pressure to tax offenders in the form of the increase in quantity and quality of tax audit probability. This strategy brought tax amnesty in South Africa succession. Indonesia has conducted tax amnesty programs twice in 1965 and 1984, but both of the programs have been a failure (Santoso and Setiawan, 2009). Ragimun (2012) added the cause of the failure of Indonesia's 1984 tax amnesty was the program not being followed by reformations in tax systems as a whole. At that time, revenues from oil and gas mainly dominated National income.

Research involving tax amnesties have been done throughout the years and by many studies. This specific area of research is particularly interesting because while tax amnesty always been seen as the most practical way to generate tax revenue in short amount of time (Malik and Schwabb, 1991; Parle and Hirlinger, 1986). It is also viewed as an imposition towards tax compliance. An honest taxpayer sees this program as an unfair treatment towards them because tax offenders could get by just by paying a few tax penalties (Recherberger et al., 2010; Alm et al., 1991). So, this program can suffer the loss of compliance from honest taxpayers. As happen in India (Purnomolastu, 2017), reoccurring tax amnesty raised expectations towards other future tax amnesties, so it decreased future tax compliance. This program also is seen as components of reform in tax administrative system (Mikesell, 1986).

Methods used in studies about amnesties mostly including survey, collecting data and using experimental. Recherberger et al. (2010) have done research focused on social psychological factors, such as perceptions of justice and punishment objectives. Alm et al. (1990) also researched tax amnesty using experiment method. The research purpose is to learn on predicted behavioral from taxpayers that based on several factors that are thought to affect the individual's decision to pay taxes. The study wants to test a hypothesis of compliance following tax amnesty. According to the result, future compliance will decrease following tax amnesty, because it affected honest taxpayers that see the programs as a reward for tax offenders, but if the program is accompanied and possibly followed by enforcement from the government; in the form of tax penalties; the level of tax compliance increases.

Indonesia still holds a lot of tax potential, mainly from higher wealth taxpayers. The 
number of tax revenues collected from Income tax $(\mathrm{PPh}) 21$ and $\mathrm{PPh} 29$ only about four trillion until eight trillion rupiahs. While in actual the potential from PPh 21 and PPh 29 is reaching 200 trillion rupiahs. This statement also supported by the amount of deposit account guaranteed by deposit insurance agency (LPS) for high wealth taxpayers which amount to above two billion rupiahs. Indonesia uses tax progressive system where the rate of tax collection with the percentage that increases with the higher the amount used as the basis of taxation, and the percentage increase for any given amount each time it rises. According to PPh 21's tariff, a taxpayer with an income of 1 billion and 2 billion will be subject to the same tax rate. Which both will be a tax for income above 500 million in progressive terms, this is considered unfair to taxpayers with a wealth of 1 billion, because the taxpayers considered himself charged more tax rates but still have to pay the same tax rate with 2 billion taxpayers. This is one of the reasons as for why taxpayers with higher income tend to avoid paying their taxes. The tendency of the avoidance from higher taxpayers sees as a problem towards Indonesia's tax compliance. Aside from the loss of tax basis potential, it also causes the loss of tax revenue. Tax amnesty program is one of the ways to bring back the previous tax deviant along with increasing the compliance of higher income taxpayers.

The tax amnesty program in Indonesia lasted for nine months divided into three periods. The first three months, the tariff used is the lowest which is $2 \%$. Based on data released by the Directorate General of Taxation (DJP), it is during this period that many taxpayers report their wealth. The reason being that the $2 \%$ rate is the lowest, so the taxpayer seeks to exploit the profit by paying the tariff as small as possible. At the end of the period of the tax amnesty program, the taxpayer who passes the audit probability and proves not to report all his assets will be giving a penalty. The applied penalty is $200 \%$. According to Alm and Beck (1993), the tax amnesty program has the potential to reduce the level of compliance of long-term taxpayers, because honest taxpayers consider this forgiveness program as a shortcut for tax evaders and it is considered unfair to the honest taxpayers. Thus, Alm et al. (1990) added that the tax amnesty program should accompany by government efforts in the form of a tax penalty to improve long-term compliance. The tax penalty will encourage the taxpayer psychologically to report his assets on the tax amnesty program. Christian et al. (2002) also studied the factors of subsequent filling based on empirical data in Michigan.

Indonesia also faced with a low level of tax ratio. This low rate of tax ratio is due to low taxpayer compliance rate. The government is trying to make tax reforms to increase the tax ratio. The changes were carried out with improvements to the system of audit probability and development of its human resources. One of the regulations that have done is the disclosure of Financial Informations; according to Research (Juanda et al., 2010) which examines the tax compliance rate in the self-assessment system by using the experimental method stated that the probability of audit probability has a positive relationship with the tax compliance level. A high level of audit probability will increase tax compliance if accompanied by high tax penalties will increase taxpayer compliance that increases the amount of tax amnesty program participation. Ross (2012) argues that, in addition to the audit probability, publication efforts from the government are an appropriate step to increase taxpayer participation in tax amnesty programs. 
Although there are many types of research about tax amnesty in some countries, there are not yet researches using Indonesia as the focus of the study. Indonesia undergoes the tax amnesty programs in the year of 2016 with the purpose to collect revenues and as well as letting the tax evaders to pay their taxes. As stated above, Indonesia faced with the low compliance, primarily from higher wealth taxpayers. These tax evaders have potential to raise national revenue, so the government thought of a way to bring back these tax evaders in tax forgiving programs that are called tax amnesty. However many problems arise surrounding the programs itself, as mentioned above the programs if not followed by government force will lower the tax compliance, in other words, will cause the program to fail. This research does with the purpose of studying the factors that thought to be relevant with the decision of taxpayers to comply with the recent tax amnesty program. These factors will analyze whether it will affect the taxpayer's decision to meet in tax amnesty program or not.

The experimental method is used explicitly because it involves the behavioral study of taxpayers that is compliance. The reason is that studying compliance is not possible to be done through field study. Compliance is not a something directly can be asked to each taxpayer whether the taxpayer is honest or not, so to study compliance it needs a tool where the behavioral of taxpayers can observe, that is through experiment. They purely decide the decision made by each taxpayer in the experiment, and this decision will lead to the tax compliance in the program.

These four factors along with the interaction between the four elements will be analyzed to see the effect on taxpayer compliance as the response. In this study, the compliance sees from the size of the unit of assets declared from which it should report, the value of the assets maintained from which it should indicate, and the taxpayer's participation. Therefore this study aims to: First, analyze the influence of wealth factor, tariff period, tax penalty and audit probability opportunities towards assets units declared during the tax amnesty program. Second, examine the impact of wealth factor, tariff period, tax penalties and audit probability opportunities towards the value of the assets proclaimed at tax amnesty program. Third, analyze the influence of wealth factor, tariff period, penalty and audit chance for probability towards taxpayers participation in tax amnesty program.

\section{Method}

The type of data used in this study is the primary data. The primary data obtained are derived from economic experiments because the necessary data for this study is not yet available in Indonesia, so it needs to generate through economic experiments. There are four factors with each factor having two levels as seen in Table 2. So, there will be 16 treatment combinations. A total of 16 treatment combinations will test to 96 students of IPB as a unit of the experiment.

The experimental design used in this study was Factorial Randomized Block Design (RAKF) with four factors by incorporating repeat components. The RAKF model used can be seen in Equation (1). 


$$
\begin{gathered}
Y_{i j k l}=\mu+\alpha_{i}+\beta_{j}+\delta_{k}+\gamma_{l}+(\alpha \beta)_{i j}+(\alpha \delta)_{i k}+(\alpha \gamma)_{i l}+(\beta \delta)_{j k}+(\beta \gamma)_{j l}+ \\
\left.(\delta \gamma)_{k l}+(\alpha \beta \delta)_{i j k}+\alpha \beta \gamma\right)_{i j l}+(\beta \delta \gamma)_{j k l}+(\alpha \beta \delta \gamma)_{i j k l}+\theta_{m}+\varepsilon_{i j k l}
\end{gathered}
$$

where $i=1,2 ; j=1,2 ; k=1,2 ; l=1,2$

with, $Y_{i j k l}$ is: First, The percentage of assets units declared from the supposedly reported level of wealth the $i$-th, in the $j$-th rate period, on the $\mathrm{k}$-th tax penalty, and at the $l$-th audit probability; Second, the percentage of asset value incurred from what should be reported of the level of the wealth the $i$-th, at the $j$-th rate, on the $k$-th tax penalty, and at the $l$-th audit probability; Third,the percentage of the taxpayer's participation of the level of wealth $i$-th at the $j$-th rate, on the $k$-th tax penalty, and at the $l$-th audit probability $\mu$ : Average acceptance in general (regardless of 4 factors); $\alpha_{i}$ is the effect of the level of wealth of the $i$-taxpayer, $(i=$ 1 for low wealth, $i=2$ for high wealth); $\beta_{j}$ is the influence of the tariff period of the $j$-th tax amnesty, ( $j=1$ for the tariff of 2 periods, $j=2$ for the tariff of 3 periods); $\delta_{k}$ is the effect of the $k$-th tax penalty ( $k=1$ for a $200 \%$ penalty, $k=2$ for a $400 \%$ penalty); $\gamma_{l}$ is the effect of $l$-th audit probability opportunity, ( $l=1$ for probability $25 \%, l=2$ for probability $75 \%$.

Tabel 2. Factors and Levels

\begin{tabular}{ccc}
\hline Index & Factors & Level \\
\hline i & Wealth & $1=$ Low \\
& & $2=$ High \\
j & Tariff Periods & $1=2$ Tariff Periods $(2 \%, 8 \%)$ \\
& Tax Penalty & $2=3$ Tariff Periods $(2 \%, 3 \%, 5 \%)$ \\
k & Audit Probability & $2=200 \%$ \\
& & $1=25 \%$ \\
& & $2=75 \%$ \\
\hline
\end{tabular}

The model will be analyzed using variance analysis (ANOVA). If the F-test statistic shows the tested factors and their interactions have a significant effect on the response, and then LSD tests will follow. The simulation of economic experiments based on induced value theory with incentive use (Friedman and Sunder, 1994). The experiment is based on environment control to allow the experimenter to only analyze the effect of the factors towards the response (Juanda, 2009). The population of this research is all the tax evaders who should have joined tax amnesty with the understanding of the consequences if they decide to join tax amnesty programs where they have to pay tax based on the level of tariff and if they choose not to participate amnesty programs that will charge with a tax penalty. The sample used is college students of Bogor Agricultural University (IPB) with the same understanding with the taxpayers who should have joined tax amnesty programs.

In this experiment, the student acts as a taxpayer with a given unit of assets and cash. Each asset represents the high wealth and low wealth. The taxpayers with low wealth have 
carried a total of six units with the value range from 10 million rupiahs until 500 million rupiahs. The taxpayers with high wealth were given a total of twelve units with the value range from 550 million rupiahs until 6 billion rupiahs. The enumerator will then act as a government by conducting a tax amnesty program. For this research, there is two type of tariff periods; the two tariff periods is where the lowest rate $2 \%$ is extended for six months, while the three tariff periods is following with the current tax amnesty programs. At the end of the period, the taxpayer will audit with given probability for each taxpayer; taxpayers who get the opportunity checked and found not reporting all his assets will be given tax penalty. So the taxpayers were able to choose whether to fully report their assets in exchange paying for tax ransoms or avoid participating in tax amnesty programs with the probability to be given tax penalty for the number of assets hidden. At the end of the experiment, the student will be given incentive converted into rupiah according to how many of the wealth is left.

\section{Result and Discussion}

The flow of discussion in this study that will be divided based on the response of this study, namely declared assets units, the value of reported assets and taxpayer participation. Each discussion in the section will analyze the primary factor along with the interaction between elements on each response. For the first response, variance analysis will be used since it fulfilled normal distribution and homogeneity assumptions, after that the study will be followed by a simple bar chart graphics to see the means between the level of each factor. While for the last two assumptions, will only use mean difference analysis followed by bar chart because both of the premises not met. The value of significance used is $10 \%$,

The first respon is assets units declared. In this response, the only amount of assets units are focused on determining whether the factors are going to influence the decision of units stated. The analysis used was variance analysis using the model above. For low wealth taxpayers given six assets units, while for high wealth taxpayers, given 12 assets units. Based on the result of variance analysis in Table 3, it is found that the wealth factor and tax penalty were significant. This means that the difference of a taxpayer's wealth affect the taxpayer's willingness to report the unit of his assets. As seen in Figure 2, taxpayers with lower wealth tend to include their assets to be reported in tax amnesty program. This data is convenient with the finding in the current condition in Indonesia where high wealth or higher income taxpayers tend to avoid paying their taxes.

The cause, first of all, is depicted above where the higher wealth taxpayers are feeling unfair towards progressive tax system, where they should pay the same rates without considering the amount of their wealth. Second, in this program both of taxpayers with high and low wealth are imposed on the same amount of tax penalty which is $200 \%$ (or $400 \%$ ), this will put a great deal on lower wealth should they be found being dishonest towards their reports. The amount of penalty charged to taxpayers with lower wealth is unusually high, they may have some wealth valuable enough to keep from reporting them, but the idea of being charged $200 \%$ (or $400 \%$ ) will undo their intention, so they likely choose to comply. 
Puri Mahestyanti. The Determinants of Tax Compliance in Tax Amnesty Programs

Table 3. Percentage of Wealth Factors, Tariff Periods, Tax Penalty and Audit Opportunities for Assets Units Declared

\begin{tabular}{|c|c|c|c|c|c|}
\hline Source & $\begin{array}{l}\text { Sum of } \\
\text { Squares }\end{array}$ & df & $\begin{array}{l}\text { Mean } \\
\text { Squares }\end{array}$ & $\mathbf{F}$ & Sig \\
\hline Corrected Model & $15887.242 \mathrm{a}$ & 33 & 481.43 & 2.01 & 0.01 \\
\hline Intercept & 657194.4395 & 1 & 657194.44 & 2737.21 & 0.00 \\
\hline Wealth & 1278.746024 & 1 & 1278.75 & 5.33 & $0.02^{*}$ \\
\hline Tariff_Periods & 27.21230686 & 1 & 27.21 & 0.11 & 0.74 \\
\hline Tax_Penalty & 1051.900975 & 1 & 1051.90 & 4.38 & $0.04^{*}$ \\
\hline Audit & 444.9059005 & 1 & 444.91 & 1.85 & 0.18 \\
\hline Repetition & 102.9271456 & 2 & 51.46 & 0.21 & 0.81 \\
\hline Wealth * Tariff_Periods & 588.9387605 & 1 & 588.94 & 2.45 & 0.12 \\
\hline Wealth * Penalty & 113.6323763 & 1 & 113.63 & 0.47 & 0.49 \\
\hline Wealth * Audt & 167.1304654 & 1 & 167.13 & 0.70 & 0.41 \\
\hline Tariff Periods * Tax_Penalty & 259.31185 & 1 & 259.31 & 1.08 & 0.30 \\
\hline Tariff Periods * Audit & 167.1305532 & 1 & 167.13 & 0.70 & 0.41 \\
\hline Penalty* Audit & 1333.382165 & 1 & 1333.38 & 5.55 & $0.02 *$ \\
\hline Wealth * Tariff_Periods * Tax_Penalty & 0.051454992 & 1 & 0.05 & 0.00 & 0.99 \\
\hline Wealth * Tariff_Periods * Audit & 37.50039581 & 1 & 37.50 & 0.16 & 0.69 \\
\hline Wealth *Tax_Penalty *Audit & 407.4601526 & 1 & 407.46 & 1.70 & 0.20 \\
\hline Tariff_Periods * Tax_Penalty * Audit & 45.27277045 & 1 & 45.27 & 0.19 & 0.67 \\
\hline Wealth * Tariff_Periods *Tax_Penalty * Audit & 425.9758917 & 1 & 425.98 & 1.77 & 0.19 \\
\hline Other Factors & 524.7413176 & 16 & 524.74 & 2.19 & 0.14 \\
\hline Error & 8956.294045 & 62 & 559.77 & & \\
\hline Total & 14885.99266 & 96 & & & \\
\hline Corrected Total & 687967.6739 & 95 & & & \\
\hline
\end{tabular}

a. R Squared $=.516($ Adjusted R Squared $\left.=.269),{ }^{*}\right)$ sig. $10 \%$ Source: Data Processed 
Figure 2. The Difference between High Wealth and Low Wealth in assets unit declared

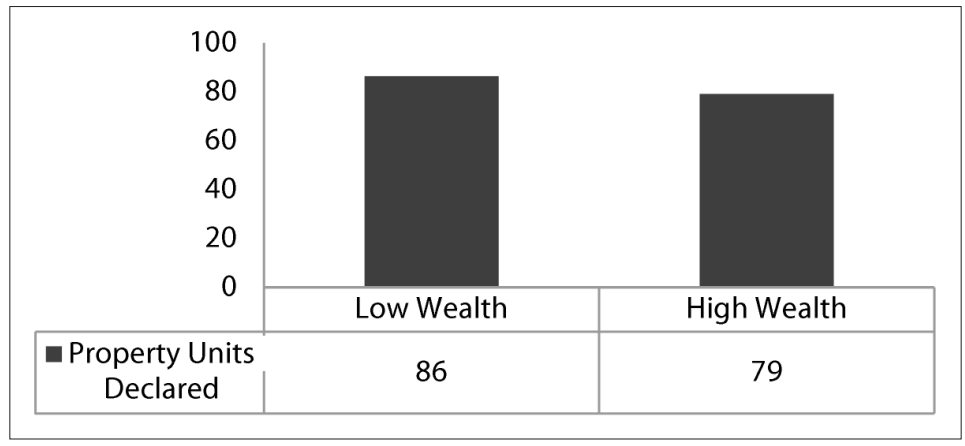

On the other side, taxpayers with higher wealth have $7 \%$ less unit declared in the program compared to low wealth income. In this experiment, the top wealth gave assets with very high value. So, the tendency for high wealth to avoid participating in tax amnesty program is quite high. They have the incentives to keep the wealth from being reported. Because if they can avoid being an audit, the wealth will belong to them entirely without being charged by paying tax ransoms in tax amnesty programs. This thought is what the most of high wealth taxpayers will choose, so the likelihood of compliance of them indeed is low.

Figure 3. The Difference between Tax Penalty $200 \%$ and Tax Penalty $400 \%$ in assets unit declared

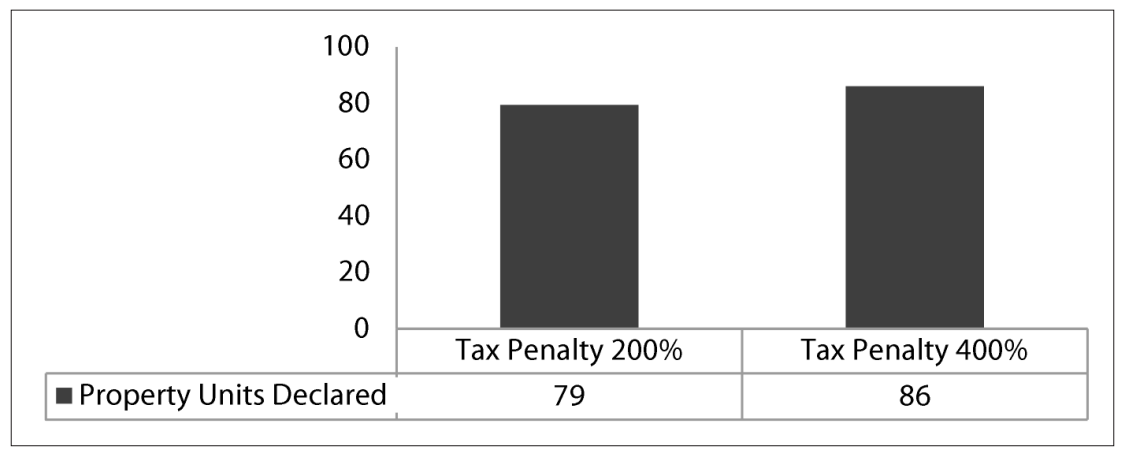

The factor of tax penalty also is statistically significant according to Table 3 . The high tax penalties on the tax amnesty program affect the taxpayer's willingness to report the unit of his assets. As seen in Figure 3, when taxpayers faced with a higher tax penalty, their compliance will raise for about $10 \%$ more units reported. Indonesia applied $200 \%$ tax penalty at the end of tax amnesty programs, according to this experiment, the higher the rate of tax penalties encourages the taxpayer to be more compliant. So, if Indonesia were to set up the tax penalty higher, it would result in higher compliance. Although practically speaking, the current value of tax penalty is already high enough to push some taxpayers to report their taxes. This fact is by the research of Juanda et al. (2010) that the higher the rate of tax penalties the higher the level of tax compliance is.

Commonly, taxpayers will choose the lowest rate possible for paying their tax rates in the tax amnesty programs. In the current tax amnesty, the lowest rates are in the first three 
months, and according to data collected from DJP, the most assets declared are in the first period. For this experiment, the period of the lowest rates which is $2 \%$ extended for six months, so for the total the tax amnesty only have two periods tariff.

Figure 4. The Interaction between Wealth and Tariff Periods in assets unit declared

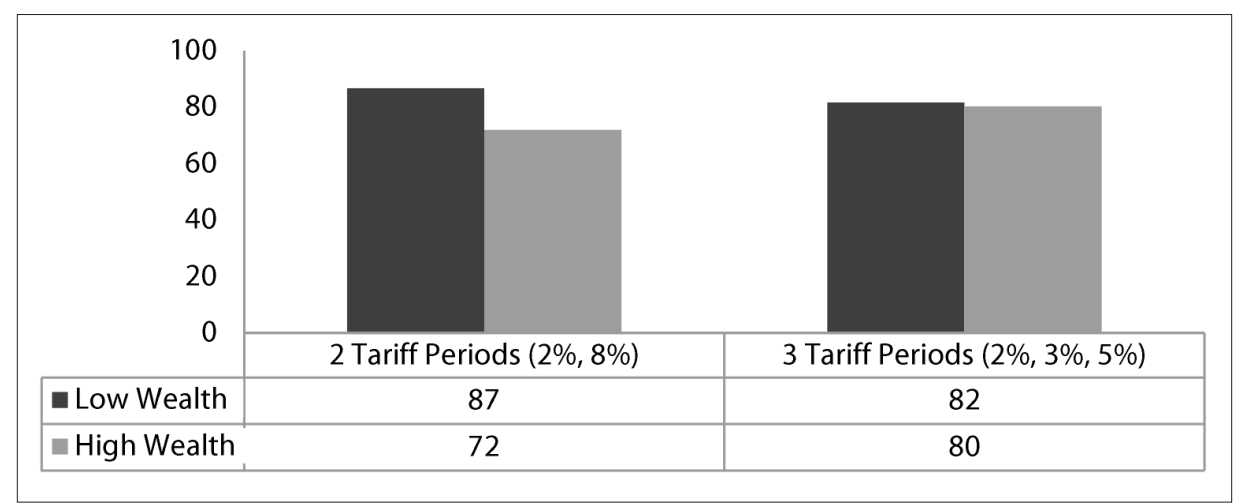

As seen in Figure 4, there is only difference in the response in 2 tariff periods between low wealth and high wealth. But, from the Figure 4 the amount of assets unit declared from low wealth still is higher than those announced from high wealth, no matter how the periods are regulated, the lowest rate tariff would always be the favorite. The more detailed picture of each assets unit reported in 2 tariff periods can be seen in Figure 5.

Figure 5. Detailed assets unit declared during 2 Tariff Periods

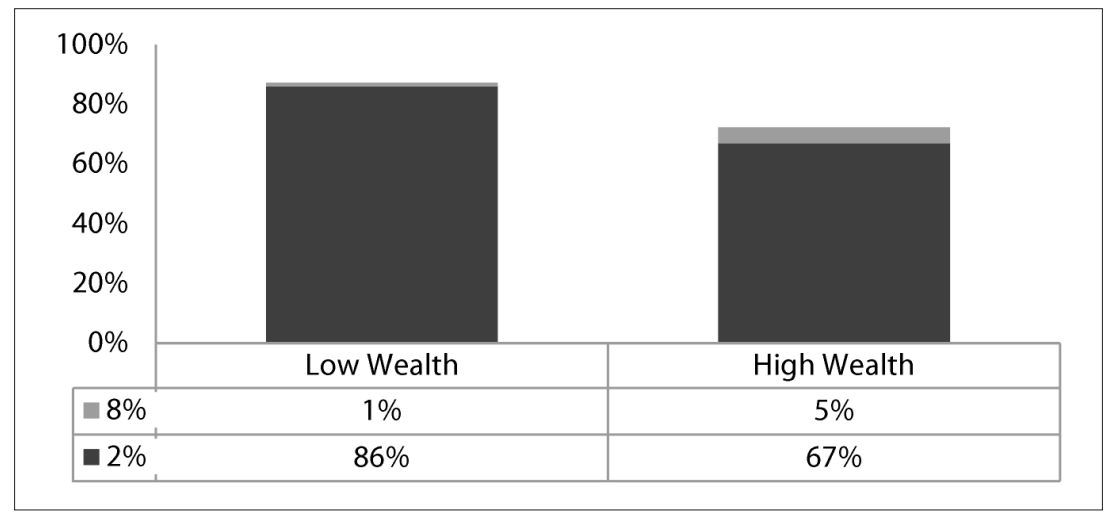

Tax audit also has a significant share in determining tax compliance. The result of tax audit was not statistically significant according to Table 3. However, if the factor were to interact together with a tax penalty, the effect will be substantial. As seen in Figure 6, when taxpayers are faced with loose audit probability, and lower tax penalty the amount of units declared is smaller when compared to the units stated in the condition of stricter audit probability and higher tax penalty. If seen from lower tax penalty, the unit reported rose by $11 \%$ in when the taxpayer faced with more stringent audit probability. Taxpayers will be charged with $200 \%$ tax penalty into their assets if found dishonest during the tax amnesty 
programs, moreover, with more rigorous audit probability the chance of being an audited rose. This condition is enough to push the taxpayers to report their assets unit when faced with more stringent probability.

Figure 6. The Interaction between Tax Penalty and Audit Probability in assets unit declared

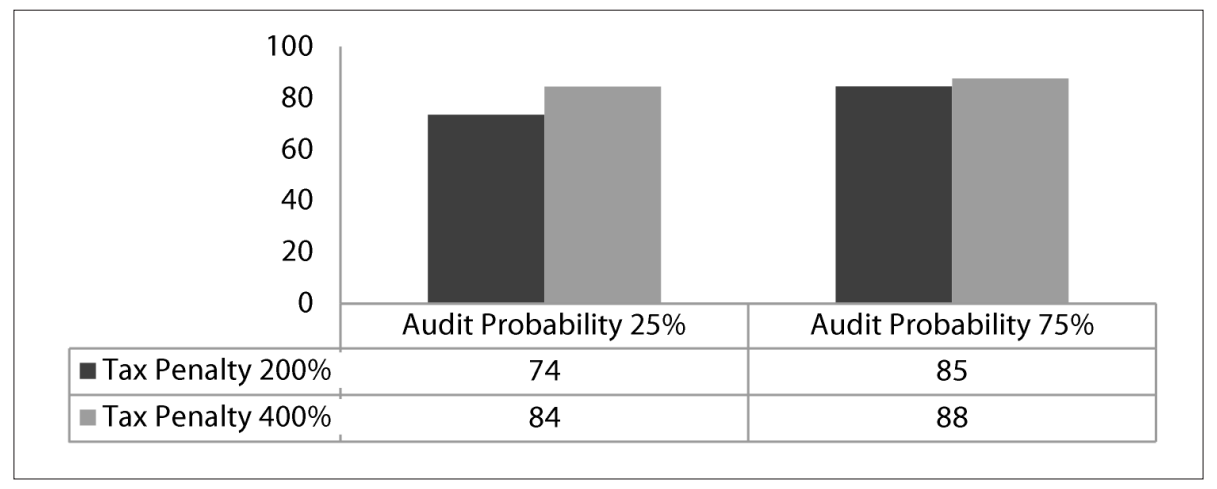

Taxpayers would think twice before decide to avoid paying their taxes in higher audit, so in this condition the level of compliance is high. However in the condition of tax penalty is $400 \%$ there are no differences in the response of unit reported. The reason is although there is a rise of unit reported in audit chance of $75 \%$, the level of tax penalty of $400 \%$ is already high enough so the taxpayers would not find any difference between a lower audit and higher audit. They are focused on how high the penalty if they were to avoid paying taxes. The difference of response depends on tax penalty. If a condition of high penalty and high audit were met, there is no reason for taxpayers to avoid their taxes. So, they will comply, this result is convenient with the result found by Alm et al. (1990) that a good tax amnesty should be followed by government enforcement in the form of the audit to increase tax compliance.

Assets values and taxpayer participation are discussed together in this section. The analysis was done with the mean test because classical assumptions were not met. In Table 4, there are two respons with each response shows percentage, variance, and sign of each factor and interaction. The analysis in this section was done with the hypotheses whether the two of the level makes a difference in the respon or not, or in other words whether the difference in the two-level will cause the taxpayers to comply or not.

The assets value in here means the actual amount of assets of each taxpayer owns, between low wealth and high wealth there is a real difference of assets value. As explained in the procedure of experiment, that for small wealth taxpayers the range of assets value is 1 million rupiah to 500 million rupiahs. While for high wealth taxpayers, the scope for assets value is 550 million rupiah until 6 million rupiahs. Participations of taxpayers measured from whether the taxpayer participating (as in reporting) their assets or not in the tax amnesty program. 
Puri Mahestyanti. The Determinants of Tax Compliance in Tax Amnesty Programs

Tabel 4. Percentage of Wealth Factors, Tariff Periods, Tax Penalty and Audit Opportunities for Assets Value Declared

\begin{tabular}{|c|c|c|c|c|c|c|}
\hline \multirow{3}{*}{ Condition } & \multicolumn{6}{|c|}{ Respons } \\
\hline & \multicolumn{4}{|c|}{ Assets Value Declared } & \multicolumn{2}{|c|}{ Participation } \\
\hline & (\%) & Variance & Sig. & (\%) & Variance & Sig. \\
\hline Low Wealth & 87.90 & & & 99.31 & & \\
\hline High Wealth & 84.05 & Heterogen & 0.221 & 99.31 & Homogen & 1 \\
\hline 2 Tariff Periods (2\%, 8\%) & 85.12 & & & 98.61 & & \\
\hline 3 Tariff Periods (2\%, 3\%, 5\%) & 86.82 & Heterogen & 0.495 & 100 & Heterogen & $0.04^{*}$ \\
\hline Tax Penalty $200 \%$ & 81.35 & & & 99.31 & & \\
\hline Tax Penalty $400 \%$ & 90.59 & Heterogen & $0.002^{*}$ & 99.31 & Homogen & 1 \\
\hline Audit 25\% & 81.90 & & & 99.31 & & \\
\hline Audit 75\% & 90.04 & Heterogen & $0.013^{*}$ & 99.31 & Homogen & 1 \\
\hline Low Wealth and 2 Tariff Periods & 89.78 & & & 98.61 & & \\
\hline High Wealth and 2 Tariff Periods & 80.45 & Homogen & 0.166 & 98.61 & Homogen & 1 \\
\hline $\begin{array}{l}\text { Low Wealth and } 3 \text { Tariff Periods } \\
\text { High Wealth and } 3 \text { Tariff Periods }\end{array}$ & $\begin{array}{l}86.01 \\
87.63\end{array}$ & Homogen & 0.749 & $\begin{array}{l}100 \\
100\end{array}$ & Homogen & 1 \\
\hline $\begin{array}{l}\text { Low Wealth and } 2 \text { Tariff Periods } \\
\text { Low Wealth and } 3 \text { Tariff Periods }\end{array}$ & $\begin{array}{l}89.78 \\
86.01\end{array}$ & Heterogen & $0.064^{*}$ & $\begin{array}{l}98.61 \\
100\end{array}$ & Homogen & 0.088 \\
\hline $\begin{array}{l}\text { High Wealth and } 2 \text { Tariff Periods } \\
\text { High Wealth and } 3 \text { Tariff Periods }\end{array}$ & $\begin{array}{l}80.45 \\
87.63\end{array}$ & Heterogen & $0.012^{*}$ & $\begin{array}{l}98.61 \\
100\end{array}$ & Heterogen & 0.088 \\
\hline $\begin{array}{l}\text { Tax Penalty } 200 \% \text { dan Audit 25\% } \\
\text { Tax Penalty } 400 \% \text { dan Audit 25\% }\end{array}$ & $\begin{array}{l}73.28 \\
90.52\end{array}$ & Heterogen & $0.001^{*}$ & $\begin{array}{c}100 \\
98.61\end{array}$ & Heterogen & 0.165 \\
\hline $\begin{array}{l}\text { Tax Penalty } 200 \% \text { dan Audit 75\% } \\
\text { Tax Penalty } 400 \% \text { dan Audit 75\% }\end{array}$ & $\begin{array}{l}89.43 \\
90.67\end{array}$ & Heterogen & 0.443 & $\begin{array}{l}98.61 \\
100\end{array}$ & Heterogen & 1 \\
\hline $\begin{array}{l}\text { Tax Penalty } 200 \% \text { dan Audit 25\% } \\
\text { Tax Penalty } 200 \% \text { dan Audit } 75 \%\end{array}$ & $\begin{array}{l}73.28 \\
89.43\end{array}$ & Heterogen & $0.014^{*}$ & $\begin{array}{c}100 \\
98.61\end{array}$ & Heterogen & 0.217 \\
\hline $\begin{array}{l}\text { Tax Penalty } 400 \% \text { dan Audit 25\% } \\
\text { Tax Penalty } 400 \% \text { dan Audit 75\% }\end{array}$ & $\begin{array}{l}90.52 \\
90.67\end{array}$ & Homogen & 0.671 & $\begin{array}{c}98.61 \\
100\end{array}$ & Heterogen & 0.5 \\
\hline
\end{tabular}

*)Sig: $10 \%$

As shown in Table 4, for the response of assets value declared, the higher tax penalty will increase assets value stated. There are 3\% more of assets value announced when taxpayers are faced with a higher penalty as seen in Figure 7. 
Figure 7. The Difference between Tax Penalty $200 \%$ and Tax Penalty $400 \%$ in assets value declared

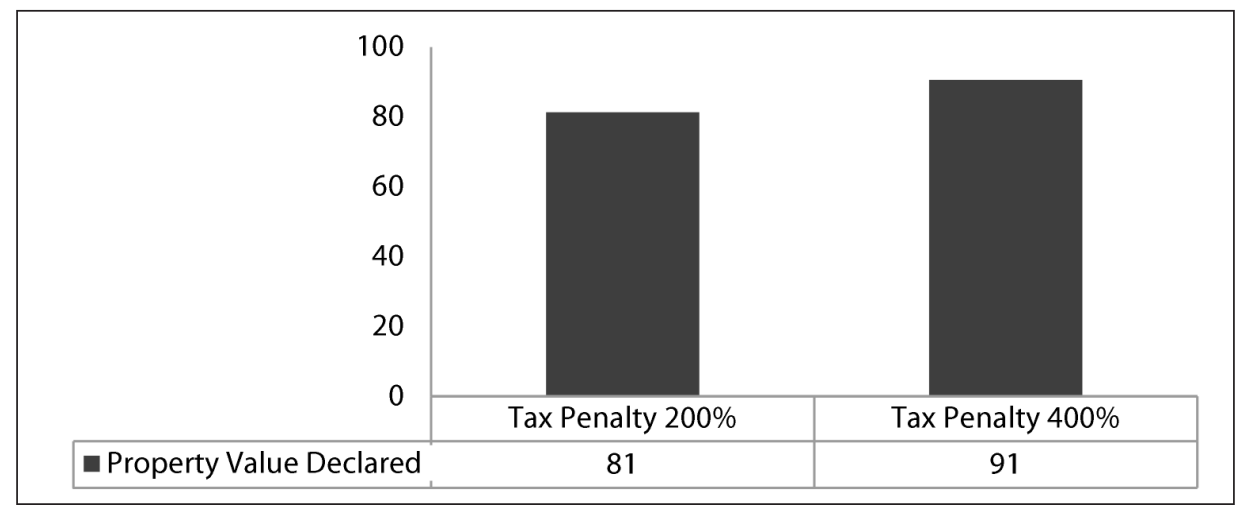

It is shown that the tax amnesty program with higher tax penalty rate will increase the compliance, same as seen in the previous response of assets unit declared. High tax penalties forced the taxpayer to report his assets when the rate of tax penalties is increased to $400 \%$ the amount of assets value indicated by the taxpayer increases by $2 \%$. The rate of the tax penalty undoubtedly will affect the taxpayer decision in this program; they are forced to think how much they will be charged if they were dishonest. If they are found dishonest at the end of the program, they will be charged with $200 \%$ of their value assets. Juanda et al. (2010) has researched with experimental setting the tax penalty in 200\% and audit probability $75 \%$ and found that the higher the tax penalty rate is, the higher the level of compliance will. The same also happens with the factor of-of tax penalty where the higher the chance of being audited the higher the value reported will be (See Figure 8).

Figure 8. The Difference Between Audit Probability of $25 \%$ and Audit Probability of $75 \%$ in Assets Value Declared

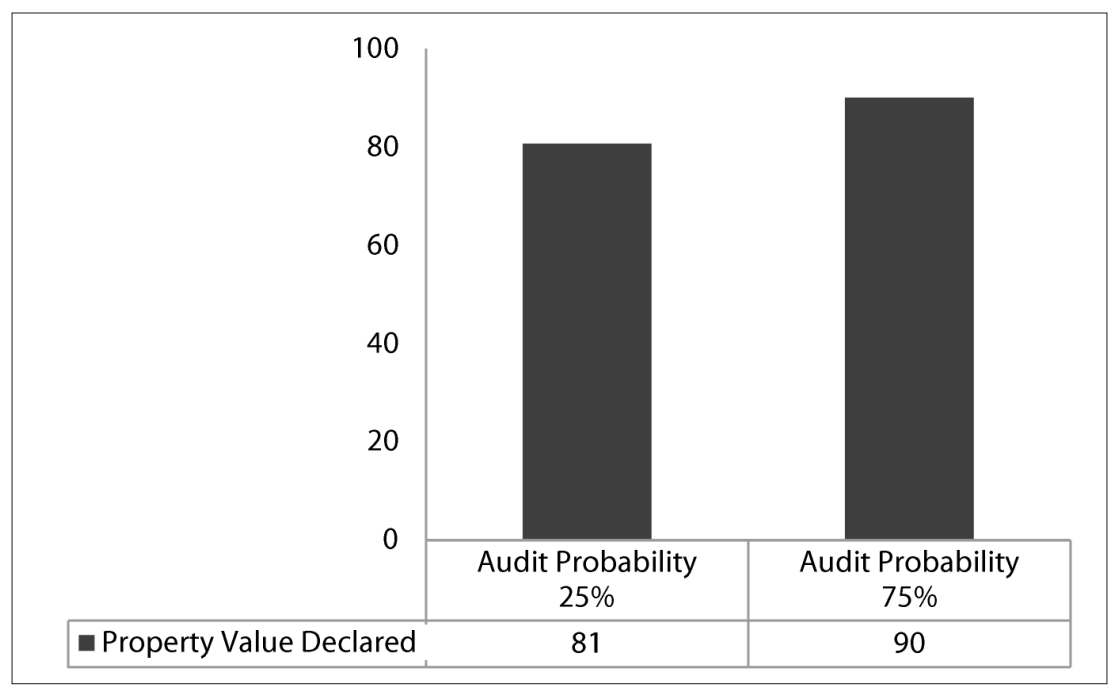

The tax amnesty programs in Indonesia followed by a type of audit as stated in Financial Openness in PMK Number 70/PMK.03.2017 where each Bank has to report to tax officer 
about the information of taxpayers with more than 1 million assets on the account. This rule is a way for the government to ensure that no tax evaders will be freed from paying their taxes. The amount of 1 million is primarily to target the higher wealth taxpayers because of they likely higher to not comply as proven in the experiment. The government enforcement by doing an audit of tax amnesty programs will raise the compliance. The higher chance of the tax evaders being audited will result in them to comply thus increase the tax compliance in general. As stated by Alm (1999) that the tax amnesty programs will follow by an effort from the government will raise the tax compliance.

Figure 9. Interaction between tax penalty and audit probability in assets value declared

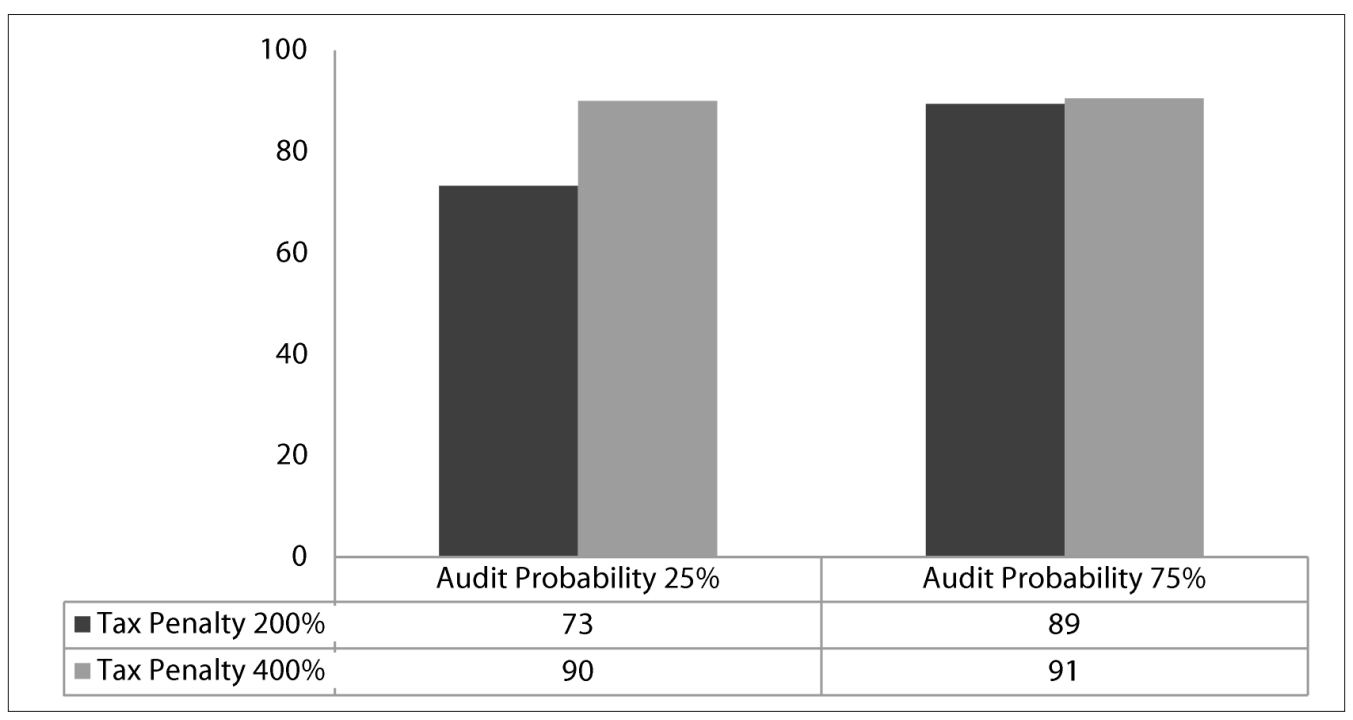

As shown in Table 4, there is interaction between tax penalty and audit probability. Figure 9 shows at a 200\% tax penalty there is a difference in response when the taxpayer faced with higher audit probability, when the audit probability opportunity increased into the stricter chance of being audited, the number of reported assets value increases by $14 \%$. While at a tax penalty of $400 \%$, both did not experience differences in response. This indicates that increasing audit probability opportunities will improve taxpayer compliance, while in a tax penalty of $400 \%$ because the tax penalty rate is high, there is no difference in response when taxpayers are faced higher audit probability. At each audit probability level, the higher the tax penalty, the higher the amount of reported assets value. This fact is by some studies that the tax amnesty program accompanied by government efforts in the form of tax penalties and inspection opportunities will improve taxpayer compliance (Juanda et al. 2010; Alm et al. 1990).

From Table 4, there are interactions between wealth and tariff periods on both responses. In assets, value declared's response, taxpayers showing more value reported in 2 tariff periods. Same as the response in assets value stated, the lowest rate of tariff $2 \%$ is preferable among taxpayers to declare their assets. Interestingly, in both tariff periods, taxpayers with low wealth also have higher assets value reported and participation compared to taxpayers with high wealth. The taxpayers who want to join the tax amnesty 
programs will consider paying them in the first period because having the lowest tariff to pay with their previously evading tax seen as a benefit towards them. The number of value assets each of taxpayers has it the decision to comply. Taxpayers need to consider which periods they need to join in paying the smallest amount possible. Therefore the first period with the lowest tariff which is $2 \%$ has the most significant amount of assets value declared.

Figure 10. Detailed participation between 2 Tariff Periods and 3 Tariff Periods on Property Value Declared

\begin{tabular}{|c|c|c|}
\hline \multicolumn{3}{|l|}{$85 \%$} \\
\hline \multicolumn{3}{|l|}{$84 \%$} \\
\hline \multicolumn{3}{|l|}{$83 \%$} \\
\hline \multicolumn{3}{|l|}{$82 \%$} \\
\hline \multicolumn{3}{|l|}{$81 \%$} \\
\hline \multicolumn{3}{|l|}{$80 \%$} \\
\hline \multicolumn{3}{|l|}{$79 \%$} \\
\hline \multicolumn{3}{|l|}{$78 \%$} \\
\hline $77 \%$ & 2 Tariff Periods ( $2 \%, 8 \%)$ & 3 Tariff Periods $(2 \%, 3 \%, 5 \%)$ \\
\hline$\square 8 \%$ & $3 \%$ & \\
\hline $5 \%$ & & $1 \%$ \\
\hline$-3 \%$ & & $1 \%$ \\
\hline$=2 \%$ & $82 \%$ & $80 \%$ \\
\hline
\end{tabular}

As for the response of taxpayer's participation, more taxpayer is participating in 3 tariff periods, with the detailed stacked involvement in each tariff is explained in Figure 12. The lowest rate that is $2 \%$ holds the highest participation among the other rates. In the tax amnesty program in Indonesia, the periods are divided into three periods for each period for three months long. The first period has the lowest tariff, which is $2 \%$, so if the tax evaders decided to join tax amnesty in the first period, they only need to pay $2 \%$ from their wealth. This fact is the best tariff for tax evaders who reason because once they pay their share of $2 \%$ from their wealth, they will free from their previous tax evasions, so the participation in the first three months is high. The dishonest taxpayers who seek forgiveness will join the first period where the rate is the lowest. This taxpayer indeed inline with the fact that most of the tax collected in the tax amnesty programs are mostly from the first period, taxpayers use this first three months with the lowest rates to pay the taxes. In this experiment, the lowest tariff that is $2 \%$ lengthened into six months period. If the $2 \%$ was the reason the government able to collect a huge amount of taxes then with the period being longer surely the amount of tax collected will raise.

As seen in Figure 11, the two tariff periods makes no difference to increase the amount of tax collected or in this matter the number of people participating. In the two tariff periods, the tariff increased drastically to $8 \%$ that only have $3 \%$ people participating in this period. The huge gap between the first period of the second period affect the taxpayers to join tax amnesty in the first period. However, looking at the two tariff periods, the lowest tariff of $2 \%$ 
still be the favorite where most of the taxpayers participating. Afterall the taxpayer's still wants to join mostly in the period where the tariff is the lowest.

\section{Figure 11. Detailed participation between 2 Tariff Periods and 3 Tariff Periods on Taxpayer's Participation}

\begin{tabular}{|c|c|c|}
\hline \multicolumn{3}{|l|}{$101 \%$} \\
\hline \multicolumn{3}{|l|}{$100 \%$} \\
\hline \multicolumn{3}{|l|}{$99 \%$} \\
\hline \multicolumn{3}{|l|}{$98 \%$} \\
\hline \multicolumn{3}{|l|}{$97 \%$} \\
\hline \multicolumn{3}{|l|}{$96 \%$} \\
\hline \multicolumn{3}{|l|}{$95 \%$} \\
\hline \multicolumn{3}{|l|}{$94 \%$} \\
\hline $93 \%$ & 2 Tariff Periods $(2 \%, 8 \%)$ & 3 Tariff Periods $(2 \%, 3 \%, 5 \%)$ \\
\hline $8 \%$ & $3 \%$ & \\
\hline $5 \%$ & & $2 \%$ \\
\hline $3 \%$ & & $1 \%$ \\
\hline $2 \%$ & $96 \%$ & $97 \%$ \\
\hline
\end{tabular}

\section{Conclusion}

The level of wealth affects the level of taxpayer compliance, evident from the three responses that the high wealth tends to disobey. Tax penalty affect the level of compliance in this program, the higher the tax penalty, the higher the compliance will be. In three of the response the tax penalty interacted with audit probability will raise the compliance, if the government set the tax penalty high then followed the program will high audit probability the compliance will rise. The tariff period indicates that the taxpayer prefers to participate in the period with the lowest rate to report assets. They seek the lowest tariff to pay with the lowest amount of their wealth. The third response which is taxpayers participation, the level of involvement is almost $100 \%$. The reason lies within the subject used for the experiment, which is the college student. The issue tends to risk-averse that is why even faced with the lower probability of being audited they still tend to comply.

Indonesia should focus on taxpayers with high wealth, with the current condition of many of taxpayers with high wealth avoid their taxes; it is the government duty to create higher enforcement to bring back the tax offenders. Tax amnesty programs were proved to bring back some of the tax offenders into paying their taxes, but in this also being an issue towards honest taxpayers who see the program as a reward for tax evaders. So to keep the taxpayers in check and not to lose the honest taxpayers, the government must do tax reforms. The stricter tax system is a must to follow tax amnesty program, to increase the tax compliance, by implying a more stringent audit specifically for high wealth taxpayers. There is a need for follow-up after the tax amnesty program ends to ensure high tax compliance.

\section{Acknowledgement}

In arranging this research, a lot of people have provided motivation, advice, and support for the researcher. In this valuable chance, the researcher intended to express her gratitude 
and appreciation to all of them. The researcher's deepest appreciation goes to her beloved parents, for the endless love, pray, and support, and her sister for reminding to keep going and never giving up.

\section{References}

Alm, J., McKee, M.J., \& Beck, W. (1990). Amazing Grace: Tax Amnesties and Compliance. National Tax Journal. Vol. 43(1): 23-27.

Alm J., \& Beck, W. (1993). Tax Amnesties and Compliance in the Long run: A Time Series Analysis. National Tax Journal. Vol. 46: 53-60.

Le Borgne, E., \& Baer, K. (2008). Tax Amnesties: Theory, Trends, and Some Alternatives. Washington DC: International Monetary Fund.

Christian, C.W., Gupta, S., \& Young, J.C. (2002). Evidence on Subsequent Filling from the State of Michigan's Income Tax Amnesty. National Tax Journal. Vol. 55(4): 703-721.

Fischer, R., Goddeeris, J.H., \& Young, J.C. (1989). Participation in Tax Amnesties: The Individual Income Tax. National Tax Journal. Vol. 42 (1): 15-27.

Friedman, D., \& Sunder, S. (1994). Experimental Methods: A Premier for Economist. Melbourne: Cambridge University Press.

Juanda, B. (2009). Metode Penelitian Ekonomi dan Bisnis (Research Method for Economics and Business). ( $\left.2^{\text {nd }} E d\right)$. Bogor: IPB Press.

Juanda, B., Ridiawati, I., \& Maryati. (2010). Kajian Tingkat Kepatuhan Pajak dalam Sistem Self-Assesment dengan Metode Eksperimen (Tax Compliance Review in SelfAssessment System with Experimental Method). Working Paper. Departement of Economics, IPB.

Joulfaian, D. (1988). Participation in Tax Amnesties: Evidence from a State. Proceedings of the Eighty-First Annual Conference on Taxation. Washington DC: National Tax Associations.

Malik, A.S., \& Schwab, R.M. (1991). The Economics of Tax Amnesties. J. of Public Economics. Vol. 46(1): 29-49. DOI: https://doi.org/10.1016/0047-2727(91)90063-8.

Mikesell, J., \& Ross, J. (2012). Fast Money? The Contribution of State Tax Amnesties to Public Revenue. National Tax Journal. Vol. 65(3): 529-562.

Parle, W.M., \& Hirlinger, M. (1986). Evaluating The Use of Tax Amnesty by State Government. Public Administration Review. Vol. 46: 246-255.

Purnomolastu, N. (2017). Comparison of Tax Amnesty Implementation in Developing Countries (Comparison Study of Tax Amnesty Implementation Between Indonesia and India 2016). Jurnal Bisnis Terapan. Vol. 1(1): 77-86.

Ragimun. (2014). Analisis Implementasi Pengampunan Pajak di Indonesia (Analysis of Tax Amnesty Implementation in Indonesia). Jurnal Kemenkeu RI. Retrieved from: https:// www.kemenkeu.go.id/sites/default/files/analisis\%20implementasi $\% 20 \operatorname{tax} \% 20$ amnesty\%20di\%20indonesia.pdf. 
Ross J.M. (2012). Forgiveness is Divine, But is it Good Tax Policy?. SPEA Insight. Indianapolis: School of Public Policy and Environmental Affairs. Retrieved from: https://spea. indiana.edu/doc/research/ross_good_tax_policy.pdf

Rechberger, S., Hartner, M., Kirchler, E., \& Hammerle, F. (2010). Tax Amnesties, Justice Perceptions and Filing Behavior: A Simulation Study. Law and Policy. Vol. 32(2): 214225. DOI: https://doi.org/10.1111/j.1467-9930.2009.00316.x.

Santoso, U., \& Setiawan, J.M. (2009). Tax Amnesty dan Pelaksanaannya di Beberapa Negara: Perspektif Bagi Pebisnis Indonesia (Tax Amnesty and Its Implementation in Some Countries: Perspective for Indonesian Businessman). Sosiohumaniora Jurnal. Vol. 11(2): 111-125. DOI: https://doi.org/10.24198/sosiohumaniora. v11i2.5413 